\title{
Fostering the Development of Social Capital to Enrich Student Experiences Through After-School Digital Tutoring Programs
}

\author{
Chientzu Candace Chou \\ University of St. Thomas, Minnesota, USA \\ Hsueh-Hua Chuang \\ National Sun Yat-sen University, Kaohsiung, Taiwan \\ Aura N. Wharton-Beck \\ University of St. Thomas, Minnesota, USA
}

\begin{abstract}
Historically, tutoring has been considered an effective way of assisting academically challenged students. After-school digital tutoring programs that foster the development of social capital could provide academic and social support for struggling students in remote areas. However, research on how after-school digital tutoring programs can foster social capital development is sparse. In this study, we used the perspective of social capital theory to examine the factors that shaped student-learning experiences in an E-Tutor Program. Specific attention was given to the types of and the strategies for developing social capital. The study utilized a case study approach to analyze data collected from interviews, documents, and observations. The findings carry programmatic implications that emphasize the importance of care pedagogy and adult connection to support student growth in similar programs.
\end{abstract}

Keywords: E-tutor, Digital Tutoring, Social Capital, After-school Program

\section{Introduction}

Digital tutoring, which refers to the use of video conferencing to provide realtime tutoring services, performs well as an after-school program to assist struggling students (Chappell, Arnold, Nunnery, \& Grant, 2015). Faced with the widening gap in academic performance and access to digital resources among students in urban and rural areas, government officials in Taiwan established a digital tutoring program called the E-Tutor Program in 2006 with the sole purpose of bridging the achievement gap. The government of Taiwan provided networked computers and individualized tutoring via videoconferencing to $\mathrm{K}-12$ students in remote and rural communities. College e-tutors were recruited to improve $\mathrm{K}-12$ e-tutees' academic performance through one-to-one online tutoring. 
Previous studies on after-school programs have emphasized the importance of developing social capital to assist teens in content learning and forging networks for professional growth (Croninger \& Lee, 2001; Miller, 2012). Social capital is considered an important asset for individuals, enabling them to establish connections to a wider network to improve their status (Lin, 1999). In education, the establishment of strong social capital can prevent dropouts and provide support for diverse students (Coleman, 1988; Miller, 2012).

The purpose of this study was to examine the factors that shaped the learning experiences of the e-tutees in the E-Tutor Program by applying the perspective of social capital theory (Bourdieu, 1986; Coleman, 1988; Lin, 1999). Specifically, we identified strategies that helped e-tutees develop social capital and investigated the types of social capital that were valuable to e-tutees. This study investigated the following two research questions:

1 What types of social capital were valued by the participants in the after-school E-Tutor program?

2 What strategies were utilized to foster the development of social capital?

We were primarily interested in exploring the perspectives of the stakeholders, especially the e-tutees. Capturing the transition of the E-Tutor Program as it moved from its original goal of promoting digital equality to the goal of cultivating social capital piqued our intellectual curiosity. We also paid close attention to the types of social capital that supported student development. Most importantly, the voices of the e-tutees provided insight into which of the structures, strategies, and resources delivered by the E-Tutor program helped them in their academic endeavors. Our findings will have important implications for how best to implement similar after-school digital tutoring programs so that they provide both academic and social support for students in rural and remote areas.

\section{Literature Review}

\subsection{Social Capital Theory}

Social capital theory provides a framework for explaining inequality in society (Bourdieu, 1986; Coleman, 1988; Lin, 1999). According to Bourdieu (1986), one's place in society is based on the accumulation of three kinds of capital: economic capital (e.g., money), cultural capital (e.g., education), and social capital (e.g., social connections). Cultural capital is acquired through selfimprovement and is often limited by one's social class. Social capital usually refers to the "membership in a group" and can be accumulated through relationships with others in a network, which can be "the name of a family, a tribe or of a school, a party" (Bourdieu, 1986, p. 286). Cultural capital and social capital often contribute to the accumulation of economic capital or wealth.

In recognition of the impact of social capital on schooling, many after-school programs now strive to leverage community resources to help marginalized students with little social capital (Katz \& Levine, 2015; Martínez, 2015; Tokumitsu, 2017; Ward, 2015). Miller (2011) investigated how community college-sponsored afterschool programs with different structures and strategies contributed to strengthening the social capital of diverse teens. Miller presented five strategies for developing positive social capital: convenient scheduling, small classes and individualized instruction, university student mentors, team building, and care pedagogy. These strategies are vital 
in fostering the development of a learning environment that emphasizes relationship building and creativity to sustain student interest in learning. Additionally, Miller (2011) differentiated between two types of relationship networks: peer bonding and connection to adults. Bonding with peers from highly diverse backgrounds in terms of race, age, gender, education, and socioeconomic class can expand students' horizons and build assets for future networks. Forging relationships with university staff and mentors can provide teens with access to potentially life-enhancing people and resources that would not be available in their own networks. Miller's (2012) study demonstrated that after-school programs with the appropriate structures and strategies could facilitate the development of positive social capital by urban families and communities. Previous research on digital tutoring has focused on the structure and instructional strategies used to strengthen the academic performance of the tutees (Burch, Good, \& Heinrich, 2016). There has been little research on the role of social capital in supporting student performance in after-school digital tutoring programs. Social capital theory provides the perfect lens with which to explain how students in afterschool digital tutoring programs expand their horizons and enhance their social networks.

\subsection{Effectiveness of Digital Tutoring}

Digital tutoring is the delivery of instruction through digital technology. There are two main types of digital tutoring: software-based tutoring and human-led tutoring, and each has several variations, such as combining a computer program with a human tutor to deliver courses over the web, having tutors meet tutees both online and in person, or providing tutoring software for personal tutoring (Burch, Good, \& Heinrich, 2016). In this section, we review the literature concerning the effectiveness of using human tutors to deliver instruction over web-based conferencing systems.

The concept of an "anywhere and anytime" digital tutoring service is popular among educators who deliver after-school programs and in-school mediation programs. An increasing number of studies are finding that digital tutoring has the potential to improve student academic performance (Burch, Good, \& Heinrich, 2016; ChanLin, Lin, \& Lu, 2012). Digital learning advocates have suggested that tutoring sessions be increasingly collaborative and learnercentered so that tutees have some degree of agency with respect to their learning (Fletcher, 1993; Flynn, 1993). A study performed by ChanLin, Lin, and Lu (2012), found that the learning engagement of $\mathrm{K}-12$ students in remote and rural area was positively affected by combining tutoring with mentoring. Furthermore, the college students not only became more tech-savvy by incorporating various digital tools into their online tutoring they also felt a sense of accomplishment when their tutees made progress. Turrentine and MacDonald (2006) suggested that, in addition to processes and clear expectations for working with tutees, the combined use of synchronous and asynchronous conferencing is an essential component of successful programs.

Burch, Good, and Heinrich (2016) identified the best practices for supporting Out-of-School Time (OST) digital tutoring programs in their study on the effectiveness of digital tutoring in $\mathrm{K}-12$ schools, including high-quality OST curricula, small group instruction, differentiated instruction, active learning, focused-sequenced-explicit instructional strategies, and connecting the content of the course to the content of the students' school day. The organization's hiring and training practices and ability to retain 
qualified tutors is critical to the success of such programs. Finally, positive tutor-tutee relationships and good community interactions are vital to the sustainability of OST programs. These best practices are especially important when working with disadvantaged $\mathrm{K}-12$ learners. However, the variety of OST programs from different providers leads to inconsistencies in their outcomes. Burch, et al. (2016) found that the outcomes of face-to-face tutoring programs were better than those of completely online tutoring programs and that students performed better when provided with synchronous tutoring rather than asynchronous digital tutoring.

In addition to the delivery format, Chappell et al. (2015) investigated the impact of one-to-one online tutoring programs on low-achieving middle school students. They compared the mathematics scores of students who had received such tutoring with those of students who did not and analyzed the perceptions of the tutors and tutees. Although there were no significant differences between the post-test scores of the tutored and nontutored students, the researchers found that, relative to their pre-test scores, there was a large absolute increase in the post-test scores of the tutored students. The tutors suggested that the persistent monitoring of student progress and the employment of guided practices and multiple explanations/ representations of target concepts were effective strategies for online tutoring. The tutees were generally positive about their experiences, particularly with respect to their learning improvement and social interactions with tutors. The tutees also offered a few negative comments about the slow pace of the instruction and the need for clearer explanations (Chappell et al., 2015). These findings are consistent with those of similar studies and confirm that struggling students benefit from individualized and focused tutoring (Burch et al., 2016).

According to previous research on digital tutoring, there is a wide range of types of digital tutoring courses, and their impacts on different learners vary with the context. The results of previous studies also suggest that the outcomes of digital tutoring programs can be improved by providing affordable home internet access, promoting stronger relationships between tutors and tutees, and providing high-quality training to online tutors (Corrigan, 2011; Price, Richardson, \& Jelfs, 2007).

Persistent challenges, such as lack of access to high speed internet or good quality teachers, cause digital inequality in rural and remote areas. The provision of digital tutoring is often intended to address this issue (Corrigan, 2011). Murphy, Shelley, White, and Baumann (2011) pointed out that the perceptions of tutees have been easily ignored because most studies have focused on the knowledge, expertise, pedagogy, and teaching styles of the tutors. Additionally, most previous research focused specifically on in-school tutoring programs and thereby ignored after-school tutoring programs. In this research, we bridged this gap by investigating after-school digital tutoring programs from the perspectives of both tutors and tutees.

\section{Background}

In 2006, the Ministry of Education in Taiwan introduced the E-Tutor Program as part of a larger digital equality initiative that aimed to bridge the achievement gap of students in grades 3 to 10 in rural and remote areas. The original goals evolved from promoting digital equality to enhancing student learning, then to developing social safety nets, providing care for disenfranchised learners, and encouraging universities and 
enterprises to engage in socially responsible activities (Ministry of Education, 2016). University students were recruited to serve as e-tutors and work on a one-to-one basis with primary and middle school students in remote areas via the E-Tutor Program's videoconferencing functionality. The actual number of participants varied each year. According to the annual report from 2015, there were 3,799 e-tutors from 27 participating universities and 2,536 e-tutees from more than $100 \mathrm{~K}-12$ schools and learning centers (Center of Care Services for Rural Area Education in Taiwan, 2015).

Each semester, the e-tutors gathered at their respective university-based computing labs twice per week for 10 weeks and provided individual e-tutees with 90-minute learning sessions. The tutees gathered at their school computing labs after school. Each university and $\mathrm{K}-12$ school computer lab was staffed with at least one faculty member and/or a tech specialist. The number of e-tutors was adjusted so that e-tutees who needed additional tutoring in mathematics or English could be accommodated. Each university assumed responsibility for training its e-tutors on the basic concepts required to design materials appropriate for instructing $\mathrm{K}-12$ learners. The E-tutors also learned to use JoinNet, the videoconferencing system involving a video camera, whiteboard, web browsing, file sharing, and an external pad for writing and drawing. A typical lesson consisted of social exchanges, reviews of previous lessons, and an assessment. In addition to the weekly online sessions, each participating university organized at least one day-long face-to-face meeting each semester for team building and tutee-tutor relationship strengthening. In this study, we assessed, from the perspectives of all stakeholders, how the student learning experiences were shaped by the development of social capital. The majority of views recorded were those of the tutees.

\section{Research Method}

We adopted a case study-based approach in this study because the absence of prior research on after-school digital tutoring programs focusing on the experiences of the tutees and their relationships with the tutors has led to the absence of a consensually accepted methodology for this type of research. Case studies can be based on data from either a single case or from multiple cases (e.g., E-Tutor Program learning hubs at different universities in different parts of Taiwan), and such data can be collected in a variety of ways, such as interviews, observations, and document reviews. Researchers use the results of case studies to comprehensively explain the dynamics of particular phenomena under specific conditions (Yin, 2003).

\subsection{Participants and Settings}

The group of participants consisted of 4 e-tutors, 5 classroom teachers, and 17 former e-tutees. The criteria for selecting the participants were as follows: (1) at least 15 years of age, (2) participation in the E-Tutor program for at least 1 year between 2006 and 2011, and (3) agreement to sign the consent forms. The consent forms for participants under the age of 18 years old were signed by their parents. We selected a 5-year window (2006-2011) so that older former e-tutees could participate in the study, as they responded to the interview questions more maturely and were able to provide insightful reflections about their learning experiences. The two sixth-graders whom we interviewed in our initial pilot interviews did not respond to our questions in an informative manner. Therefore, we interviewed former e-tutees who had already progressed to high school or university by the time of the interviews, which were conducted in late 2015 and early 2016. We purposefully selected participants 
from northern, central, southern, and eastern regions of Taiwan and the remote island of Penghu by applying a snowball sampling method to ensure that all regions were represented in the study. Snowball sampling is a strategy to "identify cases of interest from people who know people who know what cases are information-rich" (Creswell, 2013, p. 158). The E-Tutor Program ceases to track its tutees as soon as they stop participating in the program. As an incentive to recruit enough participants, the lead researcher offered a gift card of equivalent of US\$10 to each participant but not all of them accepted the offer.

We triangulated the data by ensuring that multiple perspectives were represented in our sample by including four e-tutors and five classroom teachers from different regions. The interviewers included the lead author of this study and a graduate student working on a similar thesis project. We interviewed most of the participants in-person; exceptions were made when physical meetings were not possible and in interviews were conducted by phone. Each interview lasted between 1 and 2 hours. Tables 1.1-1.3 summarize the complete profiles of the subjects, including their age, gender, education level, location, and years of study in the E-Tutor program. We started to find patterns and themes in the responses to the interview questions, which is indicative of data saturation, after 25 interviews (Fusch \& Ness, 2015; Guest, Bunce, \& Johnson, 2006).

Table 1.1 Tutor profiles

\begin{tabular}{|l|c|c|l|l|l|}
\hline & Aliases & Age & Gender & Years * & Region \\
\hline 1 & Gina & 22 & F & 2 years & North \\
\hline 2 & Tina & 27 & F & 4 years & East \\
\hline 3 & Shia & 23 & F & 3 years & North \\
\hline 4 & Polly & 25 & F & 2 years & South \& East \\
\hline
\end{tabular}

Note: * indicates years of experiences in the eTutor Program

Table 1.2 Classroom teacher profiles

\begin{tabular}{|l|c|c|l|l|l|}
\hline & Aliases & Age & Gender & Years * & Location \\
\hline 1 & Will & 50 & M & 7 years & Central \\
\hline 2 & Sue & 48 & F & 2 years & North \\
\hline 3 & Jake & 30 & M & 5 -6 years & Penghu Island \\
\hline 4 & Pam & 62 & F & 1 year & South \\
\hline 5 & Tilda & 43 & F & 10 years & East \\
\hline
\end{tabular}

Note: * indicates years of experiences in the eTutor Program 


\subsection{Data Collection}

Having decided to adopt the case study methodology, we collected qualitative data so that we could study the factors that influenced the views held by students about their learning experiences. These data involved multiple sources, including observation, documents, and interviews with stakeholders, including e-tutees, e-tutors, and $\mathrm{K}-12$ educators who worked closely with the e-tutees. The research team took field notes during their site visits to one elementary school and three universities, where they observed the e-tutors delivering courses via video conferencing facilities. We collected a range of documents, including the annual reports on the E-Tutor program and curriculum, which were available on the Ministry of Education website and which we downloaded in 2016. We will describe our interviews with the participants in the next section.

\subsection{Data Analysis}

We conducted semi-structured openended interviews (Creswell, 1998) with the aim of understanding the participants' learning experiences. The interviews were audio-recorded and transcribed verbatim in Mandarin Chinese. To verify the accuracy of the data collected, each interviewee was provided with a transcript of his/her interview before we encoded the data. We analyzed the data using the constant comparative method (Glaser \& Strauss, 1967) which is a systematic approach for identifying themes in qualitative data by combining coding with analysis. We did not specifically steer the conversations toward subjects related to social capital because the constant comparative analysis was used to extract these from the data as themes. We interpreted the data and identified themes through the lens of social capital theory. Specifically, two researchers analyzed the interview data together using the following step-by-step constant comparison method (Boeije, 2002): (1) analysis of the themes that emerged from each interview, (2) comparisons among the themes that arose within each group (e.g., e-tutees, e-tutors, and teachers), and (3) comparisons among the groups in terms of the specific themes that were identified. Two authors of this paper worked together on the first four interviews and established a coding scheme using two categories: types of social capital and strategies to support social capital development. During the second stage of coding, the first author took the lead by analyzing the remaining transcripts using the constant comparative method and refined the coding scheme while being shadowed by the second member of the pair, whose role was to review the codes completed by the first coder and annotate the texts in places where their views differed. We then used the qualitative data analysis software application NVivo to resolve these differences and modified the first coder's coding when necessary. We discuss the themes identified in the next section. 
Table 1.3 Tutees profiles

\begin{tabular}{|c|c|c|c|c|c|c|c|}
\hline & Aliases & Age & Gender & Education & School Major & $\begin{array}{l}\text { Y e a r s / } \\
\text { grades* }\end{array}$ & Region \\
\hline 1 & Zara & 19 & $\mathrm{~F}$ & $\mathrm{U}^{* *}$ & Social Work & 3 years & North \\
\hline 2 & Enya & 20 & $\mathrm{~F}$ & U Junior & Music (piano) & $\begin{array}{c}4 \text { years } \\
8-11 \\
\text { grades }\end{array}$ & North \\
\hline 3 & Vera & 19 & $\mathrm{~F}$ & $\begin{array}{l}\text { 4th year in a } \\
5 \text { - year junior } \\
\text { college }\end{array}$ & Nursing & $\begin{array}{l}3 \text { years } \\
7-9 \text { grades }\end{array}$ & North \\
\hline 4 & Jade & 20 & $\mathrm{~F}$ & $\begin{array}{l}5 \text { th year in a } \\
5 \text {-year junior } \\
\text { college }\end{array}$ & Education & $\begin{array}{c}2 \text { years } \\
7-8 \text { grades }\end{array}$ & North \\
\hline 5 & Zach & 19 & M & $\begin{array}{c}\text { U } \\
\text { Sophomore }\end{array}$ & Music & $\begin{array}{c}3 \text { years } \\
7-9 \text { grades }\end{array}$ & North \\
\hline 6 & Pat & 19 & $\mathrm{~F}$ & $\begin{array}{c}\text { U } \\
\text { Sophomore }\end{array}$ & Design & $\begin{array}{c}5 \text { years } \\
5-9 \text { grades }\end{array}$ & East \\
\hline 7 & Peggy & 19 & $\mathrm{~F}$ & $\begin{array}{c}\text { U } \\
\text { Sophomore }\end{array}$ & Design & $\begin{array}{c}5 \text { years } \\
5-9 \text { grades }\end{array}$ & East \\
\hline 8 & Yiyi & 19 & $\mathrm{~F}$ & $\begin{array}{l}5 \text { th year in a } \\
\text { private } 5 \text {-year } \\
\text { junior college }\end{array}$ & $\begin{array}{l}\text { Applied } \\
\text { English }\end{array}$ & $\begin{array}{c}5 \text { years } \\
5-9 \text { grades }\end{array}$ & East \\
\hline 9 & Wes & 19 & M & $\begin{array}{c}\text { U } \\
\text { Sophomore }\end{array}$ & Social work & $\begin{array}{c}1 \text { year } \\
8 \text { th grade }\end{array}$ & Central \\
\hline 10 & Joe & 16 & M & $\begin{array}{c}\text { 10th grade } \\
\text { Trade HS*** }\end{array}$ & $\begin{array}{c}\text { Travel } \\
\text { management }\end{array}$ & $\begin{array}{c}3 \text { years } \\
7-9 \text { grades }\end{array}$ & Central \\
\hline 11 & Jess & 16 & $\mathrm{~F}$ & $\begin{array}{l}\text { 10th grade } \\
\text { Trade HS }\end{array}$ & $\begin{array}{c}\text { Business } \\
\text { management }\end{array}$ & $\begin{array}{c}6 \text { years } \\
5-10 \text { grades }\end{array}$ & Central \\
\hline 12 & June & 16 & $\mathrm{~F}$ & $\begin{array}{c}\text { 10th grade } \\
\text { HS }\end{array}$ & & $\begin{array}{c}2 \text { years } \\
5-7 \text { th grade }\end{array}$ & $\begin{array}{l}\text { Penghu } \\
\text { Island }\end{array}$ \\
\hline
\end{tabular}




\begin{tabular}{|l|l|l|l|c|l|c|l|}
\hline 13 & Belle & 16 & $\mathrm{~F}$ & $\begin{array}{c}\text { 10th grade } \\
\text { HS }\end{array}$ & & $\begin{array}{c}\text { 1 year } \\
\text { 6-7th grade }\end{array}$ & $\begin{array}{l}\text { Penghu } \\
\text { Island }\end{array}$ \\
\hline 14 & Yula & 15 & $\mathrm{~F}$ & $\begin{array}{c}10 \text { th grade } \\
\text { HS }\end{array}$ & & $\begin{array}{c}\text { 1 year } \\
\text { 5-6th grade }\end{array}$ & $\begin{array}{l}\text { Penghu } \\
\text { Island }\end{array}$ \\
\hline 15 & Jayce & 15 & $\mathrm{~F}$ & $\begin{array}{c}10 \text { th grade } \\
\text { HS }\end{array}$ & & $\begin{array}{c}\text { 1 year } \\
\text { 5-6th grade }\end{array}$ & $\begin{array}{l}\text { Penghu } \\
\text { Island }\end{array}$ \\
\hline 16 & Hays & 15 & $\mathrm{M}$ & $\begin{array}{c}10 \text { th grade } \\
\text { HS }\end{array}$ & & $\begin{array}{c}\text { 1 year } \\
\text { 5-6th grade }\end{array}$ & $\begin{array}{l}\text { Penghu } \\
\text { Island }\end{array}$ \\
\hline 17 & Jane & 18 & $\mathrm{~F}$ & U Freshman & Management & 7-9th grade & South \\
\hline
\end{tabular}

Note: * indicates years in the E-Tutor Program and the grade levels; ** indicates University; *** indicates High School

\section{Findings and Discussions}

To identify the factors that affected e-tutees' learning experiences, we approached the data from two angles: the different types of social capital and the strategies for using the E-Tutor Program to facilitate the development of social capital.

\subsection{Types of Social Capital}

Based on our review of the interview data, we identified following themes for the types of social capital that were valued by the participants: academic learning expectations, companionship, and life coaching.

\subsubsection{Academic learning expectations.}

The E-tutees revealed that their e-tutors had higher expectations of them than did their regular classroom teachers. Students who were struggling academically reported being ignored or abandoned by their homeroom teachers prior to joining the E-Tutor program. Their e-tutors recognized their academic potential and found ways to engage them in academic learning, with clearly positive results. Many e-tutees used words such as "one-to-one learning," "personalized learning," "individualized learning," "creative strategies," "games," "multimedia," and "fun" to describe their e-tutors" methods for engaging them in academic learning. For example, one e-tutee explained that her tutor would "incorporate the names of the student and their friends or the characteristics of their schools, such as baseball teams, into review exercises to enhance their learning interests." The positive impact of e-tutors' high expectations of their e-tutees has been well documented in previous studies (Burch, Good, \& Heinrich, 2016; Kopp, Matteucci, Tomasetto, 2012).

5.1.2. Companionship. There were two levels of companionship: peer and adult companionship. First, the e-tutees highlighted the importance of the sense of companionship among themselves, the e-tutors, and their peers during the tutoring sessions. Many e-tutees emphasized that having twice-weekly access to a friendly e-tutor who listened to their issues at school and at home provided emotional comfort during their adolescent 
years. Being in the company of supportive peers and either solving academic problems or addressing issues with their network added substantial value to the program. Additionally, the e-tutees became acquainted with other students from the same school who might have different family backgrounds. Not all of the students in the E-Tutor Program were low-achieving. Therefore, membership in a heterogenous group of people from various socioeconomic backgrounds and with a range of academic abilities may have provided the individual e-tutees further advantages (Lin, 1999; Fitzgerald \& Palincsar, 2017). Many e-tutees commented that they would rather receive the tutoring service in the computer lab than at their own home because the former allowed them to learn from one another in a non-competitive environment in which their performance was not ranked or judged by teachers. Furthermore, many e-tutees considered adult companionship more important than academic learning that was summarized by one e-tutee as follows: "the companionship eased my anxiety and calmed me down when I had troubles that I couldn't share with my parents, siblings, or anyone."

5.1.3. Life coaching. Many e-tutors' roles extended beyond that of a companion to acting as a coach for the e-tutees' social and academic life. Some allowed their e-tutees to pose questions about academic work or life in general on their social media platforms. Many e-tutees saw their e-tutors as role models and aspired to become tutors themselves when they went to college; indeed, many did become tutors themselves. By sharing their own experiences as university students, e-tutors played a key role in a significant number of e-tutees decisions' regarding colleges, majors, or career paths. This type of social capital is vital for students in remote areas who lack access to vital information because adults with relevant knowledge are scarce. One e-tutee noted that "my e-tutor changed my world view and provided guidance in my life. I couldn't have made it so far without the coaching of my e-tutor." The closeness in their ages also made the tutees easier to coach because they bonded with their e-tutors easily, making them eager not to disappoint the latter. The strength of the mutual trust in their relationships improved the effectiveness of the coaching. Having a life coach is a form of social capital that teaches people important lessons about broader issues rather than academic subjects. These lessons were instrumental in motivating the e-tutees to continue advancing academically.

The main drivers that shaped the learning experiences of the e-tutees were their e-tutors' high academic expectations of them, companionship, and life coaching. These types of social capital supported the e-tutees' in their academic pursuits and career preparations. Lin's (1999) theory of social capital inequality provides a good explanation of the condition of the marginalized students. Lin (1999) stipulated that disadvantaged groups, such as females and minorities, have less access to social capital because they are not from dominant-culture backgrounds, have a limited range of connections to more resource-rich networks, and are not attached to any institutions that could provide meaningful affiliations. That the E-Tutor Program is managed by the government and operated locally by different universities show that there is strong institutional support for the local communities (Shoji, Haskins, Rangel, \& Sorensen, 2014).The development of social capital to support student growth was fostered by the diverse backgrounds of the e-tutors and e-tutees and the range of support provided.

\subsection{Strategies to Foster Development of Social Capital}

Positive social capital can expand people's 
horizons and increase the size of their social networks, thus promoting social mobility (Miller, 2011). Research has shown that we could reduce the rates at which marginalized students drop out of school by equipping them with supportive social networks (Croninger \& Lee, 2001). Purposeful strategies must be enacted to enable disadvantaged students to access resources beyond those that are available through their own social circles. The E-Tutor Program approaches this in three ways: care pedagogy, connection to adults, and university partnerships.

5.2.1. Care pedagogy. One of the key features of the E-Tutor program is that it provides personalized instruction to meet students' individual needs. However, the e-tutors offered more than personalized instruction to engage the e-tutors. The e-tutors' infusion of care into their learning activities was the main driver of their e-tutees' engagement. Nodding's care theory (2003) stipulated that a caring relationship must include three components: A consciously cares for $\mathrm{B}, \mathrm{A}$ shows acts of care, and $\mathrm{B}$ recognizes the care from $\mathrm{A}$. These components require that one understands the needs and goals of the individuals receiving care without imposing one's own agenda. The care recipients reciprocate by communicating that they have received the caring actions. This contrasts significantly with the superficial everyday conception of care because the purpose of the caring relationship is to foster growth, reduce harm, and meet the needs of the receiver. The care pedagogy extended Nodding's (2003) notion of care theory because all of the e-tutors' interactions with their e-tutees derived from the intention of fostering a community of care. Essentially, a reciprocal relationship emerged as a result of the pedagogy of care. In other words, the e-tutors made concerted efforts to understand their tutees' needs and demonstrated their care through personalized instruction and life coaching. In return, the e-tutees recognized and returned the care by striving to improve their performance.

Some e-tutees were initially unappreciative of the tutoring they were receiving. One teacher observed that, "many e-tutees might not pay attention to the tutors, thinking no one would catch them. E-tutees would browse websites or watch videos to avoid the e-tutors." It took extensive communication and patience for the care to be acknowledged and received. The e-tutees reciprocated by paying at least the minimum amount of attention required or by demonstrating understanding by actively interacting with their e-tutors. Miller (2011) coined the term "caring and creative pedagogy" to describe the instructor's "commitment to meeting each student's needs (caring) in both conventional and unconventional ways (creative) [which] appeared to lay an important foundation for relationship development among and between student and staff members" (p. 48-49). The students showed a great deal of appreciation for this approach to teaching and learning. This strategy fostered the development of social capital that, combined with care from the e-tutors and educators, contributed to learning.

5.2.2. Connection to adults. A second strategy to foster the development of social capital in the E-Tutor Program is to provide links to adults. The e-tutees emphasized that their lives changed dramatically as a result of participating in the E-Tutor program. Their self- confidence improved, and the encouragement from their e-tutors inspired them to continue their schooling. Many of the e-tutees followed the advice offered by their e-tutors, continued with their schooling, and moved beyond their own community networks. The e-tutees were motivated to follow their e-tutors' suggestions because they 
were similar in age. One e-tutee commented as follows: "having the tutor's world intertwined with our world has helped us in gaining a broader view of the world." One teacher suggested that, "the real impact is through the sharing of life experiences or moral values, something to help them understand and learn. These exchanges would have more profound, perhaps, deeper impact than improvements in grades." The effect of the constant interactions between the e-tutors and their e-tutees helped many e-tutees develop a sense of independence, improved their thinking skills, and enhanced their maturity. As summarized by one e-tutee, "I became more considerate of others because my e-tutor was older and more thoughtful. I would ask him or her for suggestions and then think about my next steps."

One e-tutee mentioned that her e-tutor discovered her talent for drawing and encouraged her to apply for the special art program at a public high school in her city. Her parents expected her to graduate from a local vocational high school and ultimately work in the service industry like all her siblings. However, the e-tutee was accepted into the high school art program, earned a scholarship to university, and is now on a career track that could ultimately lead to becoming a graphic designer. Interactions with e-tutors and other adults in the program provide e-tutees with a glimpse of the world outside their own rural communities even though they live in remote places with limited resources. Miller (2011) observed that their relationships with adults differed from their interactions with their peers because the adults "exposed the students to new opportunities and instilled newfound hope in their lives" (p. 52) in addition to helping them learn. Access to caring adults who provided tutoring services contributed to both academic learning and personal growth.

5.2.3. University partnerships. The third strategy for maximizing the development of social capital was through the affiliation of the program with universities. The results of our analysis of site visits, documents, and interview data indicate that the partnering universities played a key role in the training and retention of the e-tutors. Many of the university partners hosted campus visits for e-tutees so that they could immerse themselves in a university setting and learn more about university life. The face-to-face connections and university visits were organized by the individual universities in consultation with their partnering $\mathrm{K}-12$ schools as part of the yearlong timetable of curriculum-based and social activities. On average, each university was matched with one $\mathrm{K}-12$ school unless the university (e.g., those with Teacher Preparation programs) had the capacity to recruit and train enough e-tutors to work with more than one $\mathrm{K}-12$ school. One e-tutee was so thrilled to meet her screen friend in real life that she said that the campus visit was the highlight of the E-Tutor Program. Another e-tutee described her university visit as an "eye-opener" because she had never seen a campus that she considered to be as beautiful or magnificent. Many e-tutees claimed that they had been inspired to pursue university education as a result of their connection with universities. The universities contributed highly qualified e-tutors to provide the training and inspired young generations of future university students (Miller, 2011). 


\section{Implications and Conclusions}

In this study, we investigated the learning experiences of e-tutees enrolled in a digital tutoring program through the lens of social capital theory. Noticeably, the e-tutees' learning experiences were strongly influenced by the social and emotional support provided by the E-Tutor Program's purposeful development of social capital. We concentrated our analysis on the types of and strategies for implementing such programs. The types of social capital fostered by these programs include academic learning expectations, companionship, and life coaching. The e-tutees were motivated to try as hard as possible because they wanted to justify their tutors' high expectations of them. Their companionship with peers and tutors also provided further social/emotional support in addition to their e-tutors' life coaching. Although initially deemed unteachable, many of the e-tutees managed to continue their education at college.

Despite the seemingly insurmountable challenges, care pedagogy, connections with adults, and university partnership were identified as viable approaches to fostering social capital, expanding the horizons of students, and connecting them with wider networks. Care pedagogy developed the tutors' self-awareness by requiring them to behave in a caring manner and consider the effects of their actions in terms of meeting their tutees' needs, who then reciprocated by putting more effort into their academic endeavors (Nodding, 2003; Trout, 2018). In addition to offering academic support, the care pedagogy approach instilled the tutees with confidence to continue with their academic pursuits by showing them they had the potential to succeed. Furthermore, the connections to adults, mainly e-tutors, offers emotional support and wider opportunities via social networks that extended beyond their own communities. Finally, the partnerships with universities encouraged the growth of social capital through the provision of well-trained e-tutors, structured social activities, and educational resources that, in turn, motivated many e-tutees to pursue a university education.

Most of the previous literature discussing digital tutoring emphasized tutor training and relationship building (Chappell et al., 2015). This research contributes to the understanding of digital tutoring and social capital by highlighting strategies for developing social capital in after-school digital tutoring programs. Our findings also provide insight into the use of digital tools, such as social media, to promote the development of marginalized students by helping them accumulate social capital. Although this study was based on the E-Tutor Program in Taiwan, we could improve our understanding of how to enhance student-learning experiences by considering the results of previous studies that solidified our comprehension of the development of social capital (Miller, 2011; Riggs, 2006) and extended our understanding of the factors that students perceived to be helpful. In short, the policy and programmatic implications of this study with respect to afterschool digital tutoring programs underscore the importance of care pedagogy in the delivery of such programs. Additionally, the development of social capital through substantive institutional partnerships leverages the educational resources available to students (i.e., campus facilities, dedicated tutors, faculty experts, and affiliated $\mathrm{K}-12$ educators). 
One limitation of this study is that the self-reported data obtained from the interviews may be biased. Although we attempted to include multiple perspectives from teachers, e-tutees, and e-tutors from different regions, the responses of these groups may have been biased. Furthermore, although the development of social capital has a positive influence on sustaining student academic performance, we noticed that none of the interviewees was accepted by the top-tier universities in Taiwan. Providing just 1 or 2 years of after-school programs renders it difficult to bridge the gaps between the knowledge and performance of students from highly developed cities and those from rural areas. Deepening the impact of social capital by linking formal school routines and after-school programs is one issue that merits further inquiry. Validated survey instruments could be used to collect data for future longitudinal studies of the impact of social capital on e-tutees.

\section{Acknowledgement}

This researchers would like to acknowledge the assistance from Fulbright Taiwan through the US Fulbright Senior Scholar Program, Ms. Tze-Han Lu, director of the Center of Care Services for Rural Area Education at $\mathrm{Fu}$ Jen Catholic University, and Dr. Ji-Chyuan Yang at Cheng Shiu University in Taiwan.

\section{References}

Boeije, H. (2002). A purposeful approach to constant comparative method in the analysis of qualitative interviews. Quality \& Quantity, 36, 391-402. doi: 10.1023/ A:1020909529486

Bourdieu, P. (1986). The forms of capital. In J. Richardson (Ed.), Handbook of theory and research for the sociology of education (pp. 241-258). New York: Greenwood.

Burch, P., Good, A., \& Heinrich, C. (2016). Improving access to, quality, and the effectiveness of digital tutoring in K-12 education. Educational Evaluation and Policy Analysis, 38(1), 65-87. doi:10.3102/0162373715592706

Center of Care Services for Rural Area Education in Taiwan (2018). 2015 report. Retrieved from http://rural-caring.fju.edu. tw/web/

ChanLin, L. J., Lin, H. Y., \& Lu, T. H. (July 2012). Online after-school learning for bridging the digital divide. Proceedings of the 12th IEEE International Conference on Advanced Learning Technologies (pp. 436-437). doi: 10.1109/ICALT.2012.34

Chappell, S., Arnold, P., Nunnery, J. \& Grant, M. (2015). An examination of an online tutoring program's impact on low-achieving middle school students' mathematics achievement. Online Learning, 19(5), 37-53. Retrieved from https://files.eric.ed.gov/fulltext/ EJ1085790.pdf

Coleman, J. S. (1988). Social capital in the creation of human capital. American Journal of Sociology, 94, 95-120. doi: $10.1086 / 228943$

Corrigan, J. A. (2011). From digital divide to digital opportunity: The adoption of e-tutoring by a rural school district (Unpublished master's thesis). University of Ottawa, Canada. Retrieved from http:// www.ruor.uottawa.ca/handle/10393/20297 
Creswell, J. W. (1998). Qualitative inquiry and research design: Choosing among five traditions. Thousand Oaks, CA: Sage.

Creswell, J. W. (2013). Qualitative inquiry and research design: Choosing among five approaches (3rd ed.). Los Angels: Sage.

Croninger, R., \& Lee, V. (2001). Social capital and dropping out of high school: Benefits to at-risk students of teachers' support and guidance. Teachers College Record, 103, 548-581. doi: 10.1111/0161-4681.00127

Fitzgerald, M. S., \& Palincsar, A. S. (2017). Peer-mediated reading and writing in a digital, multimodal environment. Reading \& Writing Quarterly,33(4), 309-326.

Fletcher, D. C. (1993). On the issue of authority. In T. Flynn, \& M. King (Eds.), Dynamics of the writing conference: Social and cognitive interaction (pp. 41-50). Urbana, IL: National Council of Teachers of English.

Flynn, T. (1993). Promoting higher order thinking skills in writing conferences. In T. Flynn, \& M. King (Eds.), Dynamics of the writing conference: Social and cognitive interaction (pp. 3-15). Urbana, IL: National Council of Teachers of English.

Fusch, P. I., \& Ness, L. R. (2015). Are we there yet? Data saturation in qualitative research. The Qualitative Report, 20(9), 1408-1416. Retrieved from http://www. nova.edu/ssss/QR/QR20/9/fusch1.pdf

Glaser, B. G. \& Strauss, A. L. (1967). The discovery of grounded theory: Strategies for qualitative research. New York: Aldine De Gruyter.

Guest, G., Bunce, A., \& Johnson, L. (2006). How many interviews are enough? An experiment with data saturation and variability. Field Methods, 18(1), 59-82. doi: 10.1177/1525822X05279903

Katz, V. S., \& Levine, M. (2015). Connecting to learn: Promoting digital equity for America's Hispanic families. New York: The Joan Ganz Cooney Center at Sesame
Street. Retrieved from http://files.eric. ed.gov/fulltext/ED555584.pdf

Kopp, B. C., Matteucci, M., \& Tomasetto, C. (2012). E-tutorial support for collaborative online learning: An explorative study on experienced and inexperienced e-tutors. Computers and Education, 58(1), 12-20.

Lin, N. (1999). Social networks and status attainment. Annual Review of Sociology, 25, 467-487. doi: 10.1146/annurev. soc. 25.1 .467

Martínez, D. A. (2015). The manifestation of social capital within the mathematics, engineering, and science achievement (MESA) program University of Southern California Digital Library (USC.DL). doi:10.25549/USCTHESES-M833

Miller, P. M. (2011). Homeless Education and Social Capital: An Examination of School and Community Leaders. Teachers College Record, 113(5), 1067-1104.

Miller, P. M. (2012). Community-based education and social capital in an urban after-school program. Education and Urban Society, 44(1), 35-60. doi: $10.1177 / 0013124510380910$

Ministry of Education (2016). E-tutor program introduction. Retrieved from https://etutor. moe.gov.tw/edu_index/introduction_list. php

Murphy, L. M., Shelley, M. A., White, C. J., \& Baumann, U. (2011). Tutor and student perceptions of what makes an effective distance language teacher. Distance Education, 32(3), 397-419. doi: 10.1080/01587919.2011.610290

Noddings, N. (2003). Caring: A feminine approach to ethics and moral education (2nd ed.). Berkeley, CA: University of California Press.

Price, L., Richardson, J. T. E., \& Jelfs, A. (2007). Face-to-face versus online tutoring support in distance education. Studies in Higher Education, 32(1), 1-20. doi: 10.1080/03075070601004366 
Riggs, N. (2006). After-school program attendance and the social development of rural Latino children of immigrant families. Journal of Community Psychology, 34(1), 75-87. doi: 10.1002/ jcop.20084

Shoji, M. N., Haskin, A. R., Rangel, D. E., \& Sorensen, K. N. (2014). The emergence of social capital in low-income Latino elementary schools. Early Childhood Research Quarterly, 29(4), 600-613.

Tokumitsu, Y. (2017). In Tobey P. (Ed.), $A$ program evaluation of an alternative education program: Increasing school connectedness and building social capital ProQuest Dissertations Publishing.

Trout, M. (2018). Embodying care: Igniting a critical turn in a teacher educator's relational practice. Studying Teacher Education, 14(1), 39-55. doi: 10.1080/17425964.2017.1404976

Turrentine, P., \& MacDonald, L. (2006). Tutoring online: Increasing effectiveness with best practices. National Association for Developmental Education Digest, 2(2), 1-10. Retrieved from http://lacmsig. pbworks.com/f/tutoring\%20online.pdf

Ward, M. L. (2015). An AVID program investigation: Examining an intervention program within the context of social capital theory University of Southern California Digital Library (USC.DL). doi:10.25549/USCTHESES-M1525

Yin, R. K. (2003). Case study research: Design and methods (3rd ed.). Thousand Oaks: Sage.

\section{Contact the Author}

\section{Chientzu Candace Chou}

Professor

School of Education

University of St. Thomas in Minnesota

Email: ccchou@stthomas.edu

\section{Hsueh-Hua Chuang}

Professor

Institute of Education

National Sun Yat-sen University

Email: hsuehua@g-mail.nsysu.edu.tw

\section{Aura N. Wharton-Beck}

Assistant Professor

School of Education

University of St. Thomas in Minnesota

Email: anwhartonbec@stthomas.edu 